\title{
EXPERIMENTAL MODEL OF AN INTEGRATED APPROACH TO THE TRAINING OF LEGAL AND HEALTH CARE PROFESSIONALS ON ISSUES OF INFECTION WITH ESPECIALLY DANGEROUS INFECTIOUS DISEASES
}

DOI: 10.36740/WLek202105111

\author{
Kateryna D. Yanishevska, Tetiana V. Ivakhniuk, Hanna Y. Budko, Yurii V. Smiianov \\ SUMY STATE UNIVERSITY, SUMY, UKRAINE
}

\begin{abstract}
The aim: Developing integration training (educational) programs for medical and legal students, interns, masters, doctors

Material and methods: When performing the work, on a set of search and analytical methods: analytical, bibliographic, systemic, informational, statistical; interdisciplinary interactive teaching methods for students of Sumy State University.

Results: The results of the integrated training course are the formation of a new style of interdisciplinary relations between participants of the educational process and practical medicine and jurisprudence; new educational environment; classes with multi - and transdisciplinary experts-consultants; development of personal attitudes, future professional contacts, and practical skills.

Conclusions: The introduction of new teaching methods using an interdisciplinary integrated approach increases the level of education quality (35.8\% higher than the initial result) and conduct applied research in the field of public health, jurisprudence.
\end{abstract}

KEY WORDS: public health, infectious diseases, legal liability, medical law

Wiad Lek. 2021;74(5):1109-1113

\section{INTRODUCTION}

One of the most pressing issues of Ukrainian medicine and law in the context of active educational, medical and judicial reforms in Ukraine is the high spread of HIV, AIDS, especially dangerous infectious diseases. As a result, special attention was paid to the issues of the medical and legal protection of society from the spread of epidemics and pandemics of infectious diseases that are dangerous to human life (HIV/AIDS, other incurable infectious diseases). The modern information society points to the urgent problem of informatization (synchronization or symbiosis) of medical and legal education, the goal of which is to globally rationalize intellectual activity through the use of new information technologies, radically improving the efficiency and quality of training medical and legal students with a new type of thinking that meets the contemporary requirements. In our opinion, one of the ways to solve this problem at the level of the Public Health Department, the Department of Criminal Law Disciplines and the Forensic Medicine Department is the active implementation of training courses on the introduction of interdisciplinary integration of knowledge and skills of students in the medical and legal professions; workshops, courses on legal regulation of medical relations for health care professionals and law enforcement officers.

\section{THE AIM}

Developing integration training (educational) programs for medical and legal students, interns, masters, doctors in order to optimize and simplify the implementation of scientific approaches to specific methods for organizing preventive measures and investigating crimes related to HIV infection or other incurable infectious diseases in relation to any citizen (patient and (or) doctor), based on the experience of the EU countries.

\section{MATERIALS AND METHODS}

The article is based on a set of search and analytical methods: analytical, bibliographic, systemic, informational, and statistical. The research materials used are current modern scientific publications on the topic, monographs, legal acts that determine the relevance of the issue under study. Statistical data on cases of infectious diseases of patients and medical personnel in the performance of professional duties in Ukraine and around the world were studied. An independent survey has been conducted among students of Medical Institute and the Institute of Law of Sumy State University; health care professionals from various medical institutions; the results have been processed and summarized. The work was carried out in the framework of the competition of pedagogical innovations of undergraduate 
and postgraduate education of Sumy State University. All studies were performed after signing the informed consent. The work was approved by the Commission on Ethical Issues and Bioethics of the Sumy State University.

\section{RESULTS AND DISCUSSION}

The task of developing human resources with a high level of special innovative competencies is invariably urgent among the priority tasks of developing education in the system of health protection, public health, and jurisprudence. Currently, the system of higher education of legal specialists does not practically include separate courses concerning the medical aspects of infection and the development of infectious diseases, which may be useful in future professional activities; on the other side, for medical students, which is why most doctors, after completing their studies, do not have a sufficient level of legal awareness in the aspect of offenses, including those related to HIV infection or other incurable infectious diseases. Therefore, additional interdisciplinary trans-integration training is a doubly urgent task both at the undergraduate and postgraduate levels.

Before the implementation of the project of an experimental multi-, trans-integration program for medical students and students of the Institute of Law of Sumy State University, it was established (according to the results of a questionnaire survey of students on a specific practice-oriented situational task related to HIV infection as a result of providing medical care in the performance of professional duties) that among students of doctors, only $35 \%$ of respondents had an understanding of human rights in the field of health, which are based on the standards of the international concept of human rights; $40 \%$ of respondents were informed that patient rights, which codify specific regulations are relevant only to patients, but do not apply general human rights standards to all participants in the health care process, including healthcare professionals. $34 \%$ of legal students had a sufficient level of knowledge about HIV epidemiology, and only $8 \%$ - HIV resistance to the action of physical, chemical, and biological factors. During the educational project's implementation using multi-, trans-integration teaching methods, with a 4-stage sequential structure, $100 \%$ activation of the participants was revealed, with positive psycho-emotional mood and without indifferent and passive students. Besides, at the end of the implementation of this curriculum, an analysis of the results of the reproducibility of knowledge in the field of jurisprudence by medical students and basic medical knowledge by students of the legal specialty on the topic was carried out, which showed that after the 4 th stage, $87.5 \%$ of respondents had a sufficient level of knowledge, which is $35.8 \%$ higher than the initial result.

Not so long ago, the World Health Organization (WHO) and the Joint United Nations Programme on HIV and AIDS (UNAIDS) initiated the implementation of global strategies and compliance with the European Action Plan to end the HIV epidemic as a threat to public health in the context of ensuring a healthy lifestyle and promoting the well-being of all people of any age through universal coverage of health services, the introduction of a set of consistent services and approaches based on the principles of public health [1].

According to experts, on the one side, during the last five years, improved access of HIV-positive individuals to antiretroviral therapy stabilized the incidence of AIDS and AIDS deaths in Ukraine, on the other side, every year about a quarter of HIV-positive persons in Ukraine, identified according to laboratory tests, remained beyond medical supervision, and more than $50 \%$ of new HIV cases are diagnosed with AIDS, due to delays in seeking medical care [1]. It is generally accepted that official data do not reflect the real scale of the HIV/AIDS epidemic in Ukraine, in particular, the actual number of people infected with HIV. They only provide information about people who have been tested for HIV antibodies, who have been diagnosed with HIV infection, and who have been included in the official register of HIV cases. A much larger number of citizens may be infected, but they are not aware of their status [2]. According to the European Center for Disease Control and Prevention and the WHO Regional Office for Europe, the region of Eastern Europe and Central Asia, to which Ukraine belongs, is the only one in the world where the number of new HIV cases and AIDS deaths continues to rise [3]. In January 2020, 1,268 new cases of HIV infection were officially registered in Ukraine, 322 patients were diagnosed with AIDS, and 176 people died of AIDS [4].

The International Labor Organization (ILO) in 1999 recognized that the problem of HIV/AIDS is not only a social and medical problem but also a labor problem, as HIV can have negative consequences for the economies of countries $[5,6]$. It is worth noting that today there is no single definition of professions at increased risk of HIV infection. In general, there are two groups of professions: health care professionals, law enforcement officers, firefighters, and rescuers, who by the specifics of their activities can come into contact with blood and other biological fluids of the human body (defined by WHO and ILO) [7, 8].

During the analytical work with statistical data, we have identified a trend of increase in cases of infections in the population and health care professionals during their professional duties due to a low number of criminal proceedings for HIV infection and effective investigations into such things by both hospitals and law enforcement agencies.

Thus, Article 130 of the Criminal Code of Ukraine provides that deliberately putting another person in danger of contracting HIV or a virus of another incurable infectious disease that is dangerous to human life, a person is punished by arrest for up to three months or restriction of liberty for up to five years, or imprisonment for up to three years (paragraph 1 of Article 130). For infecting another person with HIV or a virus of another incurable infectious disease, a person who knew that he or she was a carrier of this virus is punishable by imprisonment for a term of two to five years (paragraph 2 of Article 130), and in case of intentional infection - for a period of five to ten years (paragraph 4 of Article 130) [9]. 
Statistical data on bringing persons to criminal liability for infection with the human immunodeficiency virus or other incurable infectious disease indicates that the results of the investigation of this type of crime are quite low. Thus, for 2019, 12 criminal offenses under Art. 130 of the Criminal Code of Ukraine were accounted for, of which only three were given notice of suspicion and sent to the court with an indictment [10].

As for healthcare professionals, Article 131 of the Criminal Code of Ukraine provides for criminal liability for the improper performance by a medical, pharmaceutical or other employees of their professional duties as a result of negligent or dishonest attitude to them, resulting in infection of a person with the human immunodeficiency virus or other incurable infectious diseases that are dangerous to human life.

The following actions can be qualified under Article 131: the use of contaminated, improperly disinfected medical instruments and syringes; transfusion of HIV-infected blood (its components) without laboratory diagnosis for the HIV infection; the use of other biological fluids, cells, organs and tissues without laboratory tests for HIV infection; failure by the management of the health care institution to provide the personnel of this institution with the necessary means of protection in accordance with the established list and standards.

It should be noted that crimes under Articles 130 and 131 of the Criminal Code of Ukraine are a component of the so-called latent crime, because quite a significant number of such criminal proceedings are not initiated, and as a result, are not investigated. On the one side, this is due to the fact that most law enforcement officers do not have special knowledge about the nature of HIV infection or other incurable infectious diseases, as well as about the path and peculiarities of their spread. The same can be observed for medical personnel who do not have a sufficient level of legal awareness of the specifics of violations of criminal proceedings, the collection of evidence, and their procedural consolidation and pre-trial investigation. At the same time, ordinary citizens, patients and healthcare professionals do not have a sufficient level of knowledge to protect their rights in the event of inadvertent infection with pathogens of these infections [5].

All the above shortcomings of education on HIV and ways of infection, legal aspects of infection support, etc., confirm the results of an independent (anonymous) survey of medical $(n=50)$ and legal students $(n=50)$, which was conducted at SSU and survey of healthcare professionals at the clinical bases of the Medical Institute of SSU ( $\mathrm{n}=$ 50 ) in autumn 2019. The questionnaire included questions aimed at specifying the level of knowledge and skills of respondents regarding: epidemiology of particularly dangerous infectious diseases; the algorithm of actions in case of infection when receiving medical care and performing professional duties; rules for post-contact prevention of HIV infection; knowledge of the main legal acts regarding intentional infection with particularly dangerous infections and types of legal liability for such actions; types of state legal assistance in this situation.
As for medical questions, $68 \%$ of students of the Medical Institute named the majority of diseases from the list of dangerous diseases; $82 \%$ of healthcare professionals of non-specialized departments could name up to 10 diseases; $48 \%$ of respondents of the Institute of Law named four main diseases. $80 \%$ of medical students and $92 \%$ of healthcare professionals in non-specialized departments gave a full answer about the ways of infection. All respondents were sure that the risk of contracting an infectious disease during medical manipulation was $100 \%$.

As for the legal questions, $60 \%$ of medical students said that they would contact a specialized medical institution if they suspected infection with an infectious disease; $30 \%$ would seek legal assistance, and $14 \%$ did not know how to act. $50 \%$ of healthcare professionals of non-specialized departments would apply for assistance (25\% of them would do it unofficially) to colleagues who specialize in this area; $30 \%$ would turn to colleagues and for legal aid $(20 \%$ unofficially); $15 \%$ would apply for emergency treatment, then consult experts who will give full information, pass ELISA test and drug post-exposure prophylaxis; 5\% of health workers refrained from answering.

$85 \%$ of law students answered that in case of intentional infection with HIV or other incurable diseases, after collecting the necessary supporting documentation, they should apply to law enforcement agencies with an application to open criminal proceedings, and in case of monetary expenses for diagnostics, treatment, they should also file a civil claim for compensation for material and moral damage.

As for the knowledge of the legal framework of medical activity: $20 \%$ of students of the medical Institute named the Constitution of Ukraine, the Law On Fundamentals of Legislation of Ukraine on Health Protection and the Law of Ukraine On Protection of the Population from Infectious Diseases [11], the others either refrained from answering or will search for information on the Internet. The majority of healthcare professionals, as well as students of the Medical Institute gave a generalized answer or abstained.

Law students, in addition to the legal acts listed above, noted that the main law of Ukraine that protects HIV-infected people is the Law of Ukraine On Countering the Spread of Diseases Caused by the HIV, and the Legal and Social Protection of People Living with HIV". This is what they focused on and recommended that people with HIV status should be guided to protect their rights. In their responses, they also drew attention to a number of international legal acts in the field of health, in particular, the fight against HIV: Declaration of Commitment on HIV/AIDS, G.A. Res. S-26/2 of June 27, 2001, Political Declaration on HIV/AIDS, G.A. Res. 60/262 (June 15, 2006), etc.

When asked about the governmental aid, the majority of participants in the survey of all three groups answered that they have the right to free medical care, dispensary supervision, free medicines, compensation for material and moral harm, but do not have full information about the algorithm of actions in case of such a situation.

That is why an interdisciplinary approach in the educational process of students of medical and legal specialties 
is a prerequisite for improving the level of their academic communicative competence, which in general can have a positive effect on the formation of a complex of professional competencies of future specialists. Considering this, we should refer to the experience of foreign countries, since integration processes are widespread in modern education systems in Europe and America: coordinated interdisciplinary programs; interdisciplinary integrated training courses, for the formation of a set of professional competencies of future and practicing specialists.

We have developed and implemented a project of an experimental multi-, transintegrational program with a subsequent 4-stage sequential structure: 1 ) joint lectures of teachers/experts in the medical and legal fields; 2) the evaluation of knowledge in the classroom; 3) discussion of the topic in real-life situations, case histories and court decisions; 4) general team solution of the vital situational problem on the topic of the lesson (in the form of an on-line conference with the use of interactive methods involving all participants in the process) and final individual testing in the classroom, which contains multiple-choice questions (MCQs).

When discussing the topic, students acquire the skills to determine the legal relations between various subjects in various fields, both medical and legal activities; individual analytical, integration and commission work using the knowledge and skills gained in various fields of science; comparison and justification of their own point of view with the judgments of classmates (colleagues), teachers (experts); formulation and execution of conclusions. The groups showed healthy intellectual competition, interest in solving specialized issues, and demonstrating knowledge and skills to colleagues, the collaboration between specialists of various fields and complementation of skills to create medical and legal opinions. This multi-, transintegrational training program allows increasing the level of training of specialists of a new generation for the bureaus of forensic medical examinations, medical institutions, law enforcement agencies, public administrations and local governments, which would contribute to the improvement and implementation of public policies and public administration aimed at solving problems related to the morbidity, disability and mortality among the population, protection of the rights of patients and medical workers.

\section{CONCLUSIONS}

The data of surveys conducted among students of the Medical Institute and health care professionals clearly demonstrate the following: the focus of specialists only on the issues of their specialization; unawareness of the population about legal issues; ignorance of the laws and inability to apply them in cases of violation of rights and performance of legal duties, both by health care professionals and patients. The results of the survey of students of the Institute of Law found deficiencies in knowledge about the types of particularly dangerous infectious diseases, ways of infection with these diseases, the characteristics of resistance of pathogens of these infections in the environment, which creates significant errors during the provision of legal assistance, pre-trial investigation, and court proceedings. The results of the integrated training course are the formation of a new style of interdisciplinary relations between participants of the educational process and practical medicine and jurisprudence; new educational environment; classes with multi - and transdisciplinary experts-consultants; development of personal attitudes, future professional contacts, and practical skills.

\section{REFERENCES}

1. VIL-infektsiya u doroslykh ta pidlitkiv. Klinichna nastanova, zasnovana na dokazakh. [HIV-infection in adults and teens. Clinical evidence-based guidance]. 2018: 143-144. (in Ukrainian).

2. VIL-infektsiya v Ukrayini. Informatsiynyy byuleten. [HIV-infection in Ukraine. Informational bulletin]. Kyiv. 2010; 33: 56. http://aph. org. ua/ wp-content/uploads/2016/08/Bulletin33ua.pdf. (in Ukrainian).

3. Statystyka z VIL/SNIDU. Epidemichna sytuatsiya z VIL-infektsiyi v Ukrayini stanom na 01.04.2019. [HIV/AIDS statistics. Epidemiological situation on HIV-infection in Ukraine on 01.04.2019]. Access mode: https://phc.org.ua/kontrol-zakhvoryuvan/vilsnid/statistika-z-vilsnidu. (in Ukrainian).

4. Statystyka VIL i tuberkul'ozu v Ukrayini: sichen' 2020 roku. [Statistics on HIV and tuberculosis in Ukraine: report of period in January 2020]. https://www.phc.org.ua/ news/statistika-vil-i-tb-v-ukraini-sichen2020-roku. (in Ukrainian).

5. Pravove rehulyuvannya vidnosyn u sferi zakhystu naselennya vid infektsiynykh khvorob. [Law regulation of activity in the sphere of population health protection against communicable diseases]. Official site of the Ministry of Justice of Ukraine. 2018. https://minjust.gov. $\mathrm{ua} / \mathrm{m} / \mathrm{str} \_24798$. (in Ukrainian).

6. Kruhlov Y.V., Martsynovskaya V.A., Maksymenok O.V. et al. Suchasni epidemiolohichni rysy sotsial'no znachushchykh infektsiy u konteksti rehional'nykh osoblyvostey dostupnosti ta yakosti posluh u sferi okhorony zdorovya. Materialy naukovo-praktychnoyi konferentsiyi z mizhnarodnoyu uchastyu, prysvyachenoyi shchorichnym «Chytannyam» pamyati akademika L.V. Hromashevs'koho. [Modern epidemiological specialties of social diseases in context of regional reliability and quality of health care services. Materials on scientific and practical conference with international participation, devoted to L.V. Hromashevs'kii]. Kyiv. 2018; 7. (in Ukrainian).

7. VICH/SPID: Rukovodstvo dlya inspektorov truda. [HIV-AIDS: guidelines for labor supervisor]. Geneva. International Labor 0ffice. 2007; 51. (in Russian).

8. Nakaz MOZ Ukrayiny 08.02.2013 № 104 Pro zatverdzhennya Pereliku ta Kryteriyiv vyznachennya hrup pidvyshchenoho ryzyku shchodo infikuvannya VIL. [Order N 104 of 08.02.2013 of Ministry of Health, Ukraine "About Approval of List and Criteria on Determination of High Risk Groups with HIV-infection"]. http://aids.dp.ua/ upload/iblock/bdb/ bdbcea47a2414b37da9054a7836d7d47.pdf. (in Ukrainian).

9. Loshyts'koho M.V. Naukovo-praktychnyy komentar Kryminal'noho kodeksu Ukrayiny. Stanom na 21 lyutoho 2019 roku. [Scientific practical commentary of The Criminal Code of Ukraine on 21.02.2019]. Kyiv: Vydavnychyy dim «Profesional». 2020; 198. (in Ukrainian).

10. OfficialsiteofGeneralProsecutorOfficeofUkraine. https://www.gp.gov.ua/ ua/stst2011. html?dir_id=113897\&libid=100820\&c=edit\&_c=fo\#. (in Ukrainian). 
11. Pro zakhyst naselennya vid infektsiynykh khvorob Zakon Ukrayiny from 06.04.2000 № 1645-III. [0n Protection of Population against Infectious Diseases, from 06.04.2000, Document 1645-III]. https://zakon.rada.gov. ua/laws/show/1645-14. (in Ukrainian).

\section{ORCID and contributionship:}

Kateryna D. Yanishevska - 0000-0002-3648-5543 ${ }^{A, F}$

Tetiana V. Ivakhniuk - 0000-0001-5851-2218 ${ }^{A, B, E}$

Hanna Y. Budko - 0000-0002-3567-2996 ${ }^{A, E}$

Yurii V. Smiianov - 0000-0002-3311-4210 C, D, E

\section{Conflict of interest:}

The Authors declare no conflict of interest.

\section{CORRESPONDING AUTHOR}

Tetiana V. Ivakhniuk

Sumy State University

1 Sanatorna st., 40018 Sumy, Ukraine

tel: +380502078873

e-mail: t.ivakhnjuk@med.sumdu.edu.ua

Received: 26.12 .2020

Accepted:31.03.2021

A - Work concept and design, B - Data collection and analysis, C - Responsibility for statistical analysis,

D-Writing the article, $\mathbf{E}$-Critical review, $\mathbf{F}$ - Final approval of the article 